\title{
Thermogenesis in newly hatched Eider (Somateria mollissima) and Long-tailed Duck (Clangula hyemalis) ducklings and Barnacle Goose (Branta leucopsis) goslings*
}

\author{
JOHAN B. STEEN AND GEIR W. GABRIELSEN
}

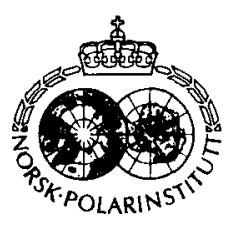

\begin{abstract}
Steen, J. B. \& Gabrielsen, G. W. 1986: Thermogenesis in newly hatched Eider (Somateria mollissima) and Long-tailed Duck (Clangula hyemalis) ducklings and Barnacle Goose (Branta leucopsis) goslings. Polar Research 4 n.s. 181-186.

Oxygen consumption and body temperature were recorded in Eider and Long-tailed ducklings and in Barnacle goslings less than 4 days old. In some ducklings organ temperatures during cold exposure and oxydative capacity of various organs were also measured. Both ducklings and goslings were perfectly homeothermic down to $-10^{\circ} \mathrm{C}$ ambient temperature. Eider hatchlings had a lower critical temperature of $23^{\circ} \mathrm{C}$. Long-tailed of $29^{\circ} \mathrm{C}$, and Barnacle goslings of $21^{\circ} \mathrm{C}$. During cold stress the area below the spine was slightly warmer than the thigh and liver. The high oxydative capacities of these organs compared to yolk, kidney, and gut indicate that the homeothermy in newly hatched ducklings and goslings depends on a combination of good insulation and a high oxydative capacity of leg muscles and liver.
\end{abstract}

Johan B. Steen, Div. of General Physiology, Department of Biology, P.O. Box 1051 Blindern. 0316 Oslo 3. Norway; Geir W. Gabrielsen, Norsk Polarinstitutt, Rolfstangveien 12, 1330 Oslo Lufthavn, Norway; January 1986 (revised April 1986).

Birds usually have a poorly developed thermogenic capacity at hatching and are dependent upon insulation from the nest and heat from their parents in order to maintain a normal body temperature (Ricklefs 1974). Striking exceptions to this general pattern are found among ducklings (Untergasser \& Hayward 1972), which are rarely brooded and can endure hours of severe cold exposure the first days after hatching (Mendenhall 1979). These ducklings are able to increase their heat production 3-5 times on exposure to cold (Koskimies \& Lahti 1964). In mammals such coldinduced thermogenesis is usually associated with brown adipose tissue (Blix \& Steen 1979). In birds thermogenic tissue is normally not found. However, Oliphant's (1983) findings indicate that this type of tissue is present in two species of birds. Heat is produced by muscular shivering, possibly also by non-shivering thermogenesis in the muscles (Barre et al. 1985).

During July 1985 we had the opportunity to study temperature regulation in hatchlings of Eider (Somateria mollissima) and Long-tailed Duck (Clangula hyemalis) at the Research Station of the Norwegian Polar Research Institute at NyÅlesund, Svalbard $\left(79^{\circ} 55^{\prime} \mathrm{N}\right)$. Eiders nest in

- Norsk Polarinstitutt Contribution No. 242. dense colonies on the mainland and on nearby islets in the ice floe-strewn Kongsfjorden. The ducklings leave their downy nest within one day after hatching in early July and usually go directly to sea. They are precocial and can swim, eat, and dive as soon as they reach the water. They go on land only occasionally, but are rarely brooded (Mendenhall 1979). For comparison we also studied 3-4 day old hatchlings of the Barnacle Goose (Branta leucopsis), which hatch in the same environment, but only reluctantly spend much time on water. The mean July air temperature was $6^{\circ} \mathrm{C}$, with occasional sunny days, but also with spells of high winds and snow.

In order to describe the thermoregulatory capacity of the hatchlings we measured $\mathrm{O}_{2}$ uptake $\left(\mathrm{VO}_{2}\right)$ and $\mathrm{CO}_{2}$ production $\left(\mathrm{VCO}_{2}\right)$, body temperature $\left(t_{b}\right)$, and web temperature $\left(t_{w}\right)$ under laboratory conditions similar to those facing them in the wild. This included air temperatures $\left(t_{a}\right)$ down to $-10^{\circ} \mathrm{C}$ and water temperatures of $0^{\circ} \mathrm{C}$. In order to identify organs that are particularly important in producing heat during cold exposure, we also made body composition analyses and measured the temperature of various organs in ducklings exposed to cold. Thermogenic capacity of various organs was estimated by measuring cytochrome oxidase activity. 


\section{Material and methods}

Eider and Long-tailed ducklings were either hatched in incubators or caught in the nests. Barnacle goslings were caught while foraging. All ducklings were known to be less than 2 days old, while the goslings probably were 3-4 days old.

$\mathrm{VO}_{2}$ and $\mathrm{VCO}_{2}$ were measured in an open system. Air was drawn through a $20 \times 15 \times 15$ cm, TV-surveyed plexiglass respiratory chamber situated in a thermoregulated room, dried and analyzed. Chamber temperature $\left(t_{a}\right)$ was measured within $0.1^{\circ} \mathrm{C}$ with thermocouples placed above the bird's head and read on a Fluke (2190A) digital thermometer. $\mathrm{O}_{2}$ and $\mathrm{CO}_{2}$ content in outflow gas were determined to the nearest $0.01 \%$ by a S-3 $\mathrm{A} \mathrm{O}_{2}$ analyzer (Applied Electro-Chemistry Inc.) and a Binos-2 $\mathrm{CO}_{2}$ analyzer (Leybold Heraeus) respectively. Gas flow varied between 145 and $155 \mathrm{ml} \mathrm{min}^{-1}$ and was measured to within $10 \mathrm{ml} \mathrm{min}{ }^{-1}$ with a $\mathrm{Hi}-\mathrm{Tec}$ pressure and temperature compensating flowmeter. $\mathrm{VO}_{2}, \mathrm{VCO}_{2}$, and R.Q. were calculated using conventional procedures, taking into account that, except at $R Q=$ 1 , flow into the chamber is different from flow out of it. Our method gave the same values for $\mathrm{VO}_{2}$ at thermoneutrality as did a conventional manometer method with a compensation chamber (Scholander 1949).

Oxygen consumption was measured on 6 Eider ducklings, 2 Long-tailed ducklings, and 3 Barnacle goslings. They were placed, one at a time, in the pretemperated chamber. Only when the birds had been physically inactive for at least 10 minutes were flow and gas compositions recorded. Two to four readings were taken at 5-10 $\mathrm{min}$ intervals on each individual at each temperature. Such experiments were conducted at chamber temperatures ranging from $-10^{\circ} \mathrm{C}$ to $31^{\circ} \mathrm{C}$. At the end of each experiment, oral temperature $\left(t_{b}\right)$ was recorded by inserting the thermocouple $3 \mathrm{~cm}$ down into the throat of the bird. The same bird never stayed in the chamber for more than 2 hrs at a time. Between runs they were kept in an incubator with eiderdown on the floor at $33.0^{\circ} \mathrm{C}$.

Parallel experiments were made with $10 \mathrm{~cm}$ ice water in the chamber. At the end of these experiments web temperature $\left(t_{w}\right)$ was also recorded by wrapping the web around the thermocouple. The reading reached a stable value after $10-15$ seconds.

Specific thermal conductance in cal $\mathrm{g}^{-1} \cdot \mathrm{hr}^{-1} \cdot{ }^{\circ} \mathrm{C}^{-1}$ was calculated by dividing the caloric equivalent of the $\mathrm{VO}_{2}\left(4.8 \mathrm{cal} \mathrm{ml}^{-1} \mathrm{O}_{2}\right)$ by $t_{b}-t_{a}$ at a $t_{a}$ below thermoneutrality.

Organ temperatures were measured on 5 Eider and 2 Long-tailed ducklings after exposure to -10 to $-20^{\circ} \mathrm{C}$ for 30 minutes. To this end the duckling was instantly killed by a blow on the head, the abdominal skin ripped open, and the needle ( 2 $\mathrm{mm}$ o.d.) mounted thermocouple inserted in the desired organ. The first measurement was made less than 15 seconds after the bird had been killed. The temperatures of the yolk sack, liver, and thigh were all recorded within 1 minute of killing the bird. Repeated measurements indicated a more rapid cooling of the liver than of yolk and thigh. Therefore, only the first series of measurements on each bird is presented.

Body composition was established by dissecting 4 Eider chicks (1-2 days) and weighing each organ separately. A few ducklings were frozen in a conventional deep freeze. Organs from these were later analyzed for oxydative capacity by measuring the $\mathrm{O}_{2}$ uptake of homogenates incubated with ascorbic acid, according to the method of Aulie and Grav (1979). The results must be considered as indicative only, since tissue degeneration may have occurred during the rather slow freezing procedure.

\section{Results}

\section{Air exposure}

The lower critical temperature of Eider ducklings was $23^{\circ} \mathrm{C}$. The resting $\mathrm{VO}_{2}\left(\mathrm{RVO}_{2}\right)$ was $1.73 \pm 0.20 \mathrm{ml} \mathrm{O}_{2} \mathrm{~g}^{-1} \mathrm{hr}^{-1}(\mathrm{n}=11)$ (Table 1), and the regression line for values at temperatures below $23^{\circ} \mathrm{C}$ intersected the absissa at $\mathrm{t}=40.9^{\circ} \mathrm{C}$ (Fig. 1). This compares satisfactorily with the mean of the measured $t_{b}$ of $40.0^{\circ} \mathrm{C}$ below thermoneutrality. $T_{b}$ decreased only slightly upon cold exposure, the lowest being $38.3^{\circ} \mathrm{C}$. At an air temperature of $-9^{\circ} \mathrm{C}$ the metabolism of the Eider ducklings was about 2.7 times the resting value. Specific thermal conductance is given in Table 1.

The lower critical temperature of Long-tailed ducklings was estimated at $29^{\circ} \mathrm{C}$. The $\mathrm{RVO}_{2}$ was $2.10 \pm 0.21 \mathrm{ml} \mathrm{O}_{2} \mathrm{~g}^{-1} \mathrm{hr}^{-1}(\mathrm{n}=5)$ (Table 1), and the regression line for values below $29^{\circ} \mathrm{C}$ intersected the absissa at $\mathrm{t}=41.0^{\circ} \mathrm{C}$ (Fig. 2). This compares satisfactorily with the $t_{b}$ of $39.5^{\circ} \mathrm{C}$, measured at $t_{a}=30^{\circ} \mathrm{C}$. $T_{b}$ increased slightly upon 


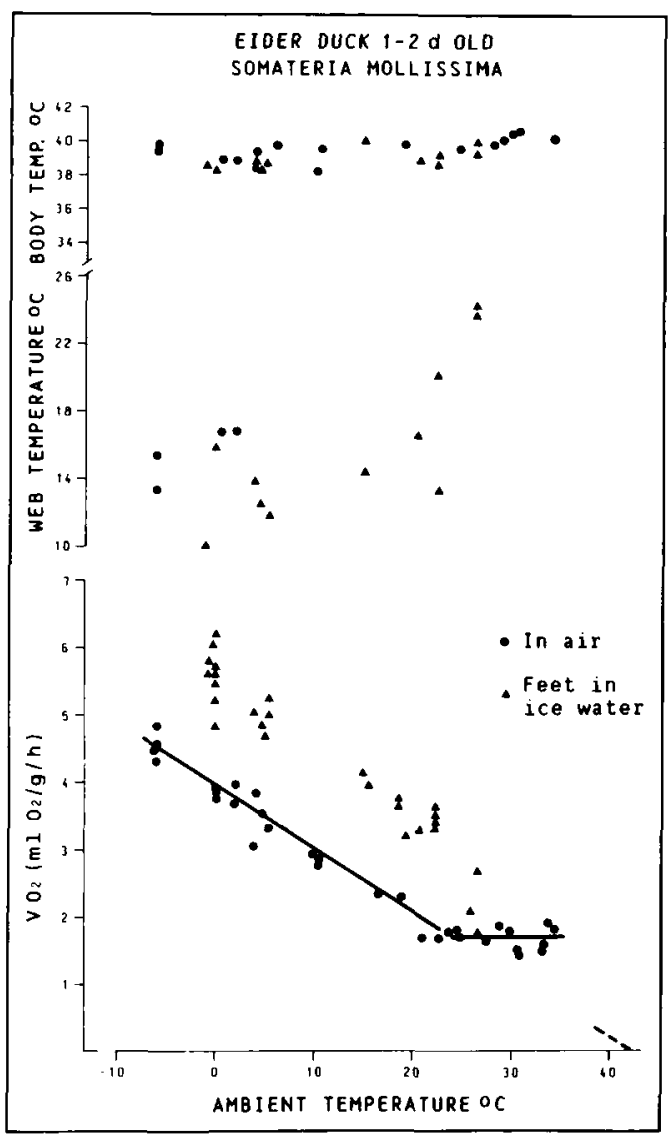

Fig. 1. Oxygen consumption, body, and web temperature of Eider ducklings at varying ambient temperatures with and without feet in ice water. Regression line at $t_{a}$ below $23^{\circ} \mathrm{C}$ is $y=-0.093 x+3.90$, c.coeff. $=0.98$.

cold exposure. At an air temperature of $0^{\circ}$ the $\mathrm{VO}_{2}$ was 3 times the resting level. Specific thermal conductance is given in Table 1.

Table 1. Body weight, resting $\mathrm{O}_{2}$-uptake, and specific thermal conductance of Eider and Long-tailed ducklings and Barnacle goslings.

\begin{tabular}{llll}
\hline & Eider & $\begin{array}{l}\text { Long-tailed } \\
\text { Duck }\end{array}$ & $\begin{array}{l}\text { Barnacle } \\
\text { Goose }\end{array}$ \\
\hline $\begin{array}{l}\text { Resting } \mathrm{O}_{2} \text {-uptake } \\
\quad\left(\mathrm{ml} \mathrm{g}^{-1} \mathrm{hr}^{-1}\right)\end{array}$ & 1.73 & 2.10 & 1.75 \\
Body weight (g) & 65 & 30 & 80 \\
Lower critical temp. $\left({ }^{\circ} \mathrm{C}\right)$ & 23 & 29 & 21 \\
$\begin{array}{l}\text { Specific thermal } \\
\text { conductance: } \\
\left.\quad \text { cal.g } \mathrm{hr}^{-1}{ }^{\circ} \mathrm{C}^{-1}\right)\end{array}$ & & & \\
In air & 0.45 & 0.82 & 0.43 \\
In air but feet in ice water & 0.66 & 0.98 & - \\
\hline
\end{tabular}

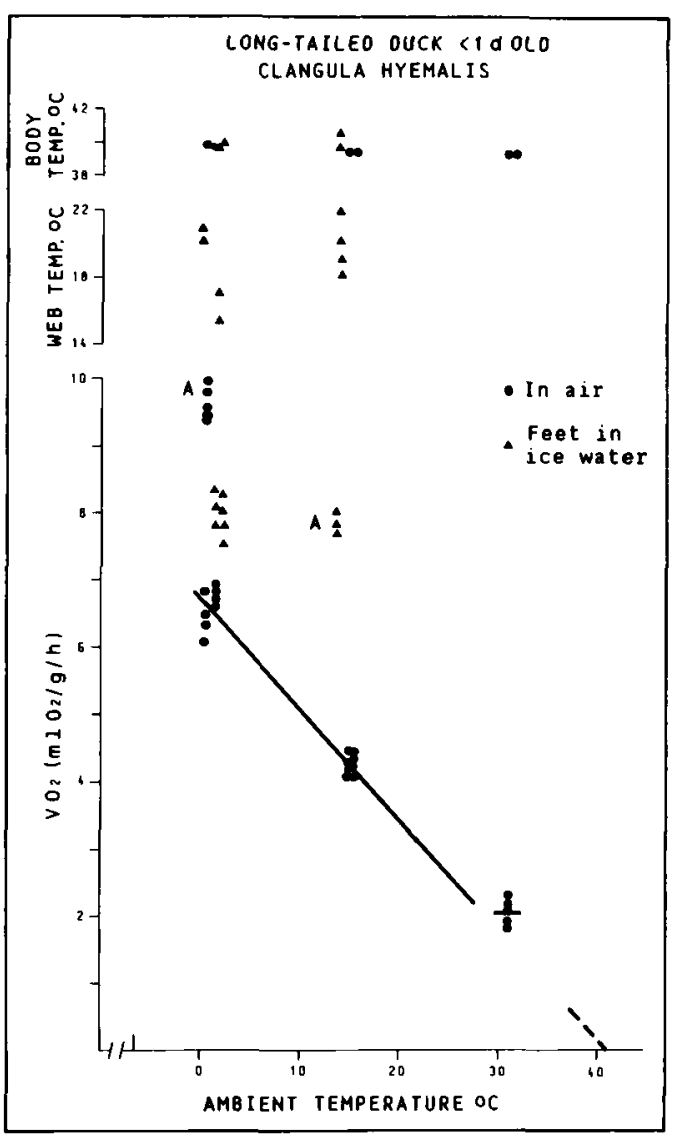

Fig. 2. Oxygen consumption, body, and web temperatures of Long-tailed ducklings at varying ambient temperatures with and without feet in ice water. Regression line at $\mathrm{t}_{\mathrm{a}}$ below $29^{\circ} \mathrm{C}$ is $\mathrm{y}=-0.164 \mathrm{x}+6.74, \mathrm{c}$. coeff. $=0.98$. $\mathrm{A}=$ active birds.

Assuming a $\mathrm{t}_{\mathrm{b}}$ of $40.5^{\circ} \mathrm{C}$ (Fig. 3) and that $\mathrm{VO}_{2}$ vs. $t_{a}$ follows Newton's law of cooling, the lower critical temperature of Barnacle goslings was estimated at $21^{\circ} \mathrm{C}$.

\section{Feet in water}

When these measurements were repeated with ice water in the respiratory chamber, the ducklings reacted differently from the goslings. The former swam quietly among the ice cubes and usually settled peacefully within a few minutes. The latter were restless. At the end of the experiment the ducklings still had a dry pelt, while the goslings were wet. $\mathrm{VO}_{2}$ of the goslings increased threefold compared to resting values at thermoneutrality, 


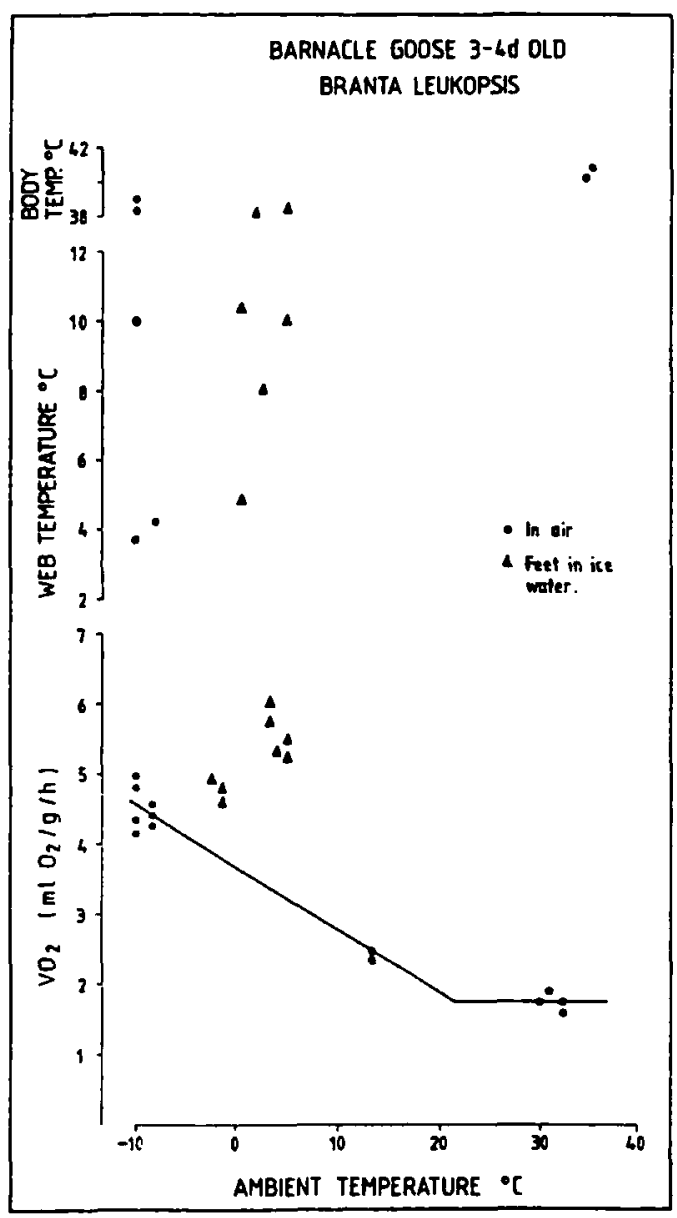

Fig. 3. Oxygen consumption, body, and web temperatures of Barnacle goslings at varying ambient temperatures. Line drawn from mean of values below $0^{\circ} \mathrm{C}$ to $+40^{\circ} \mathrm{C}$.

and despite this their body temperature $\left(38.2^{\circ} \mathrm{C}\right)$ dropped below normal (Fig. 3). $\mathrm{T}_{\mathrm{w}}$ of the goslings after 1 hour at $-7^{\circ} \mathrm{C}$ and ice water ranged between 4 and $6^{\circ} \mathrm{C}$. The thermal conductance of goslings with feet in ice water could not be obtained since the birds were active.

Contrary to the goslings, the ducklings did not have a lower $t_{b}$ value at the end of 1 hour of exposure to $t_{a}=0^{\circ} \mathrm{C}$ and ice water than after 1 hour of exposure to air at $0^{\circ} \mathrm{C}$ (Fig. 1). $\mathrm{VO}_{2}$ of Eider ducklings resting on ice water at $t_{a}=-1$ to $-2^{\circ} \mathrm{C}$ was 3 times the resting $\mathrm{VO}_{2}$. The $T_{w}$ of ducklings after 1 hour in ice water ranged between 12 and $15^{\circ} \mathrm{C}$ at $\mathrm{t}_{\mathrm{a}}$ below $21^{\circ} \mathrm{C}$. At higher $\mathrm{t}_{\mathrm{a}}$ values, $\mathrm{t}_{\mathrm{w}}$ increased sharply (Figs. 1 and 2 ).

\section{Organ temperatures and body composition}

Organ temperatures of ducklings after 30 minutes exposure to -5 to $-18^{\circ} \mathrm{C}$ are shown in Fig. 4 . The highest temperatures were always recorded from the area between the yolk sack and the spine. Thigh muscle temperature was $0.8^{\circ} \mathrm{Clower}$, and that of the liver and yolk sack lower still.

The body composition of Eider ducklings is shown in Table 2. The size of the yolk sack varied from 6 to $10 \%$, presumably according to time

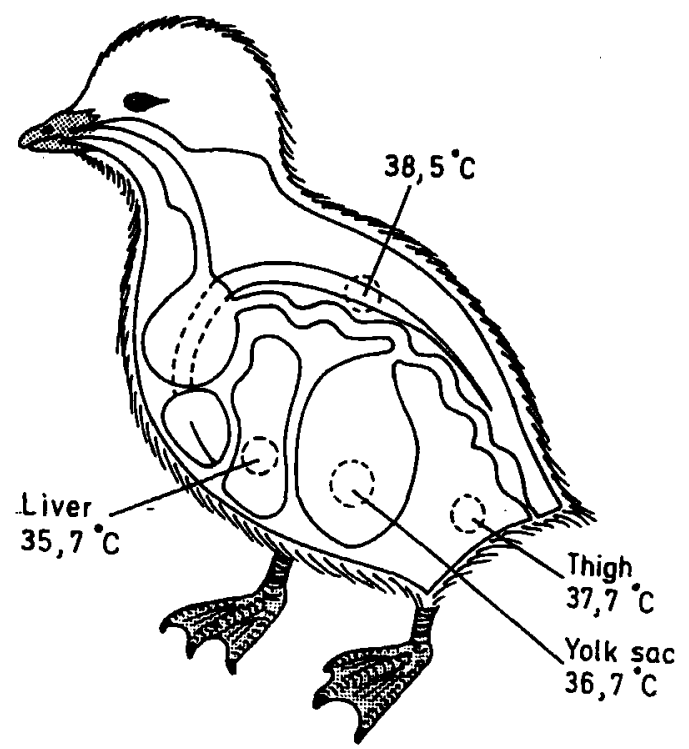

Fig. 4. Temperatures of various parts of the body of Eider and Long-tailed ducklings during cold stress. Each value is the mean of one measurement on each of 7 ducklings.

Table 2. Body composition of 3 Eider ducklings less than 2 days after hatching. Average weight of ducklings was $66.8 \mathrm{~g}$.

\begin{tabular}{lcc}
\hline & $\begin{array}{l}\text { Weight of organs } \\
\text { Organ }\end{array}$ & \% of total wt. \\
\hline Pelt w. skin & 9.5 & 14.3 \\
Wings & 1.3 & 2.0 \\
Feet w. tarsi & 5.4 & 8.1 \\
Head, neck, skeleton & 22.0 & 33.0 \\
Liver & 2.4 & 3.6 \\
Heart & 0.5 & 0.8 \\
Dissectable fat & 2.8 & 4.1 \\
Digestive system & 5.2 & 7.7 \\
Pectorals & 0.6 & 0.9 \\
Yolk & 5.9 & 8.9 \\
Fluids & 4.6 & 6.8 \\
Leg muscles & 6.7 & 9.8 \\
\hline
\end{tabular}


after hatching. The ducklings had a conspicuous layer of subcutaneous fat, and fat pads were also located at the shoulders, neck, and along the anterior of the legs. All fat accumulations were typically white. The preliminary assessment of oxydative capacity indicated considerably higher values in the leg muscles and the liver than in the yolk, gut, and kidney (Grav pers. comm.). The highest obtained value was comparable to the intra scapular brown fat found in young rats, using the same method.

\section{Discussion}

Koskimies \& Lahti (1964) and Untergasser \& Hayward (1972) demonstrated two remarkable features of newly hatched ducklings. One was their extremely well developed thermoregulation and the other that it resided mainly in their capacity to increase the metabolism when exposed to cold. The present paper presents new and supplementary information on both these aspects.

The temperature distribution within the ducklings during cold stress demonstrated that they maintain their entire body at a nearly normal temperature. This was also indicated by the close fit of the $\mathrm{VO}_{2}$ values vs. temperature to the straight line predicted from Newton's law of cooling.

The area between the spine and the yolk sack was always the warmest part of the duckling during cold stress, though there was no tissue in that area that could be suspected of high thermogenesis. Hence the yolk, gut, and kidney had low oxydative capacities. The most likely explanation is that the liver and the leg muscles are the main organs of cold induced heat production, as indicated by their high oxydative capacities, and that blood from these organs cause the hot point in the spinal region. The use of thermometers with smaller needles and more precise localization would probably give maximum temperatures in the liver and the leg muscles. Whether the coldinduced thermogenesis in the leg muscles was achieved by shivering, as is common in birds, or by non-shivering thermogenesis, as indicated by studies of Barre et al. (1985), will be a matter for future research.

Our value for resting $\mathrm{VO}_{2}$ was about $30 \%$ above that found for Eider hatchlings by Koskimies \& Lahti (1964). The difference is most likely due to a combination of the age of the ducklings and the climate of their habitat. Our chicks were 1-2 days old, while the aforementioned authors used chicks less than 1 day old. $\mathrm{RVO}_{2}$ is known to increase during the first days after hatching (Ricklefs 1974), the increase being faster in precocial birds than in altrical ones. Thus, the high $\mathrm{RVO}_{2}$ of our hatchlings seems partly to reflect the high degree of precocity of Eider hatchlings.

The high $\mathrm{RVO}_{2}$ of our hatchlings may also reflect the low ambient temperature of their environment. Thus, Weathers (1979) suggested that in adult birds $\mathrm{RVO}_{2}$ increases with increasing breeding latitude and hence with decreasing mean ambient temperature. Although the mean summer temperature at Koskimies \& Lahti's location in Finland is not known, it was certainly considerably higher than at Ny-Ålesund.

The insulation of the Eider hatchling pelt is expressed by a specific conductance of $0.094 \mathrm{ml} \mathrm{O}_{2}$ $\mathrm{g}^{-1} \mathrm{~h}^{-10} \mathrm{C}^{-1}$. In comparison, adult nonpasserine birds weighing $66 \mathrm{~g}$ (average of hatchling eiders) should have a specific conductance of 0.124 during daytime ( $\alpha$-phase) and 0.082 during the night according to the equation of Aschoff (1981). Our value also compares well with that given by Koskimies \& Lahti (1964) for Eider ducklings and other Anseriformes.

When the ducklings had ice water in the respiratory chamber, their specific heat conductance was $0.134 \mathrm{ml} \mathrm{O} \mathrm{O}_{2}^{-1} \mathrm{~h}^{-10} \mathrm{C}^{-1}$. The difference between the conductance values in air and in water/air demonstrates that the heat loss through the feet is considerable. At $+4^{\circ} \mathrm{C}$, which is within the normal range of temperatures during the hatching of chicks, heat loss from the feet constitutes $30 \%$ of the total (Figs. 1 and 2). This, in addition to the high leg temperature, indicates that the vasomotor control of leg circulation is not yet fully developed at hatching.

Acknowledgements. - This is publication No. 242 from the Norwegian Polar Research Institute, the sponsor of this work. We are grateful to Fridtjof Mehlum for assistance with the field work, to Berit Schreiner for microscopic examination of various tissues, and to the staff of the Ny-Ålesund Research Station for their skilful support. Xenia Toverud demonstrated skill and patience in typing the manuscript.

\section{References}

Aschoff, J. 1981: Thermal conductance in mammals and birds: Its dependence on body size and circadian rhythm. Comp. Biochem. Physiol. 69A, 611-619. 
Aulie, A. \& Grav, H. 1979: Effect of cold acclimation on the oxidative capacity of skeletal muscles and liver in young bantam chicks. Comp. Biochem. Physiol. 62A, 335338.

Barre, H., Geloen, A., Chatonnet, J., Dittmar, A. \& Rouanet, J.-L. 1985: Potentiated muscular thermogenesis in coldacclimated muscovy duckling. Am. J. Physiol. Regulatory Integrative Comp. Physiol. 18, R533-R538.

Blix, A. S. \& Steen, J. B. 1979: Temperature regulation in newborn Polar homeotherms. Physiol. Rev. 59, 285-304.

Koskimies, J. \& Lahti, L. 1964: Cold-hardiness of the newly hatched young in relation to ecology and distribution in ten species of European ducks. Auk 81, 281-307.

Mendenhall, V. M. 1979: Brooding of young ducklings by female Eiders. Somateria mollissima. Ornis Scand. 10, 94 99.

Oliphant, L. W. 1983: First observations of brown fat in birds. Condor 85, 350-354.

Ricklefs, R. E. 1974: Energetics of reproduction in birds. Pp. 152-292 in Paynter, R. A. (ed.): Avian Energetics. Nuttall Ornithological Club Publ. 15.

Scholander, P. F. 1949: Volumetric respirometer for Aquatic Animals. Rev. Scient. Instr. 20, 885-887.

Untergasser, G. \& Hayward, J. S. 1972: Development of thermoregulation in ducklings. Can. J. Zool. 50, 1243-1250.

Weathers, W. W. 1979: On the relationship between basal metabolic rate and breeding latitude in birds. Ecology 18, 6572. 